\title{
POHLEDY NA VÝUKU ZEMĚPISU NA 2. STUPNI ZÁKLADNÍ ŠKOLY: SOUHRNNÉ VÝSLEDKY CPV VIDEOSTUDIE ZEMĚPISU
}

\author{
DANA HÜBELOVÁ, TOMÁŠ JANÍK, PETR NAJVAR
}

\begin{abstract}
Anotace: Příspěvek shrnuje hlavní výsledky CPV videostudie zeměpisu, knimž se dospělo v letech 2005-2007. Autoři prezentuji: 1) pohled na organizační formy, v nichž se výuka odehrává; 2) pohled na fáze, v nichž se výuka odehrává; 3) pohled na vztahy mezi formami a fázemi výuky; 4) pohled na príležitosti $k$ verbálnímu projevu, které výuka nabízí. Souhrnem lze konstatovat, že zkoumaná výuka zemèpisu je silně rízena učitelem a nenabízí téměř žádný prostor pro skupinové aktivity žáků. Dominujícími organizačními formami výuky jsou: samostatná práce, rozhovor se třídou, výklad/přednáška učitele a diktát. Dominujícími fázemi výuky jsou: zprostředkování nového učiva a zkoušení/prověrka/kontrola domácí úlohy; výrazně jsou zastoupeny fáze zaměřené na práci sjiž probraným učivem (opakování, procvičování učiva, shrnutí učiva), naopak $v$ relativně malé míre jsou zastoupeny kognitivně náročnější fáze, jejichž jádrem je aplikace učiva a metakognitivní podpora učebního procesu. Co se př́ležitostí k verbálnímu projevu týče, učitel hovoří v hodině príbližně šestkrát více než všichni žáci dohromady, mezi jednotlivými učiteli a hodinami však existují značné odlišnosti.
\end{abstract}

Kličcová slova: fáze výuky, organizační formy výuky, přiležitosti k učení, videostudie, výuka zemèpisu

Abstract: The paper summarises the main findings of the CPV video study of Geography, which were collected between 2005 and 2007. The following topics are addressed: 1) modes of classroom organisation; 2) lesson phases; 3) coincidences of modes of classroom organisation and lesson phases; 4) opportunities to talk that instruction offers. The findings indicate that Geography lessons are to a great extent controlled by the teacher while limited time is allowed for students' group activities. Individual Work, Class Discussion and Teacher's Talk are the most frequent modes of organisation, while Developing New Content and Testing are the most frequent phases of instruction. Considerable amount of time is dedicated to working with previously introduced content (Revision, Practicing, Summarising), while little time is allowed for those phases which involve applying content or metacognitive reflection of the learning process. The analysis of opportunities to talk shows that on average, teacher's talking time amounts to six times the time of student talk; however, there are significant differences between individual teachers.

Key words: phases of teaching, modes of classroom organisation, opportunity to learn, video study, geography teaching 


\section{1. Úvodem}

$C P V$ videostudie zeměpisu je realizována ve spolupráci Katedry geografie a Centra pedagogického výzkumu PdF MU od roku $2005^{10}$. Jejím teoretickým východiskem je pojetí vyučování jako vytváření príležitosti $k$ učení. Předmětem analýz jsou videozáznamy 50 vyučovacích hodin zeměpisu k tématu „přírodní podmínky České republiky" pořízené u šesti učitelů $v$ 8. a 9. trí́dách základních škol v Brně a blízkém okolí (dostupný výběr). Metodologický postup CPV videostudie zeměpisu byl představen v př́spěvku D. Hübelové (2006), dále byly publikovány výsledky analýz organizačních forem a fází výuky (Hübelová, Janík, Najvar 2007).

Cílem předkládaného příspěvku je představit metodologický postup a shrnout dosavadní výsledky CPV videostudie zemépisu. Výsledky této videostudie jsou prezentovány formou pohledů na výuku - na její organizační formy, fáze a na př́ležitosti $\mathrm{k}$ verbálnímu projevu učitele a žáků.

\section{Stav řešené problematiky, teoretická východiska, cíle, otázky}

Výzkum zaměřený na výuku zeměpisu v zahraničí byl realizován především jako součást výzkumu výuky prírodovědných předmětů v mezinárodně srovnávací studii TIMSS. Mezinárodním výzkumům vyučování zeměpisu se věnovali např. $\mathrm{H}$. Haubrich (1996) a R. Gerber (2003). Jednalo se o zkoumání postavení zeměpisu ve studijních plánech různých úrovní školního vzdělávání (primární, sekundární, terciární) ve vybraných zemí světa (v roce 1996 to bylo 37 zemí, v roce 2000 celkem 32 zemí, včetně České republiky). Př́spěvek k výzkumu učiva a učení v oblasti zeměpisné orientace v prvouce a vlastivědě provedly E. Vyskočilová a A. Matoušková (1998), formou didaktického experimentu byla hodnocena vhodnost operačního přístupu ve výuce vlastivědy. Na Slovensku patří k nejnovějším výzkumům zjištování stavu úrovně vyučování geografie místní krajiny na základních školách a osmiletých gymnáziích (Hasprová 2006). Pedagogicko-psychologické aspekty učitelových otázek (frekvence otázek, typy otázek, vztah otázek a odpovědí) byly předmětem analýzy 17 audionahrávek vyučovacích hodin zeměpisu, českého jazyka, dějepisu a matematiky 8. ročníku základní školy (Pstružinová 1992). Výzkumům komunikace se věnuje P. Gavora (1987), kdy na souboru 23 vyučovacích hodin sedmi předmětů základní školy, mezi nimiž byl také zeměpis, stanovil základní komunikační pravidla. P. Gavora využil nahrávky ÚEPd SAV, v nichž byla zaznamenána výuka vlastivědy ve 4. ročníku základní školy a rovněž sloužily pro výzkum komunikace ve výuce (Gavora 2005).

Celkově lze konstatovat, že výzkum výuky zeměpisu u nás není výrazněji rozvinut. Tato skutečnost byla jedním z podnětů pro realizaci $C P V$ videostudie zeměpisu. Cílem této videostudie bylo proniknout $\mathrm{k}$ didaktickým aspektům výuky zeměpi-

10 Videostudie prováděné CPV (Centrem pedagogického výzkumu Pdf MU) jsou souhrnně nazývané CPV videostudie; tj. CPV videostudie fyziky, CPV videostudie zeměpisu, CPV videostudie anglického jazyka a CPV videostudie tělesné výchovy 
su na 2. stupni základní školy, a přispět tím k hledání odpovědí na otázky, jakým způsobem a za jakých podmínek je ztvárňován obsah vzdělávání ve výuce tohoto předmětu. $C P V$ videostudie zeměpisu je konkretizována pomocí dílčích cílů, $\mathrm{k}$ nimž jsou přiřazeny příslušné výzkumné otázky: $V$ jakých organizačních formách se odehrává výuka zeměpisu a jaké je jejich časové zastoupení? V jakých fázích se odehrává výuka zeměpisu a jaké je jejich časové zastoupení? Jaké je zastoupení organizačních forem v jednotlivých fázích výuky? Jaké př́ležitosti k verbálnímu projevu nabízí výuka zeměpisu?

\section{Metodologický postup}

\subsection{Popis zkoumaného souboru}

Vzhledem k povaze výzkumu, kdy byli učitelé nahráváni na video, jsme se rozhodli realizovat dostupný výběr. Kontaktováni dopisem byli ředitelé 45 brněnských základních škol, nižších ročníků gymnázií a škol v blízkém okolí Brna s otázkou, zda by některý z učitelů byl ochoten zúčastnit se výzkumu. Zájem spolupracovat na projektu CPV videostudie zeměpisu projevilo 11 učitelü ${ }^{11}$, z nichž tři téma "přírodní podmínky České republiky", které bylo předmětem analýz, ve školním roce 2005/06 nevyučovali. Po vyjednávání se školami bylo možné realizovat natáčení výuky s šesti učiteli, od nichž byly v průběhu měsíců srpna a zárí 2005 získány první informace - kontextuální data (aprobace, délka pedagogické praxe, počet vyučovacích hodin, téma vyučovacích hodin, počet žáků ve třídě) (obr. 1). Ve výzkumném souboru bylo zastoupeno široké spektrum škol - fakultní škola PdF MU, škola zaměřená na prírodovědné předměty, škola s rozšířenou výukou cizích jazyků; soubor obsahoval jak školy městské, tak venkovské. Co se vybavenosti škol pro výuku týče, škola od školy se značně lišila. Výuka probíhala ve specializovaných učebnách nebo v běžných (kmenových) třídách.

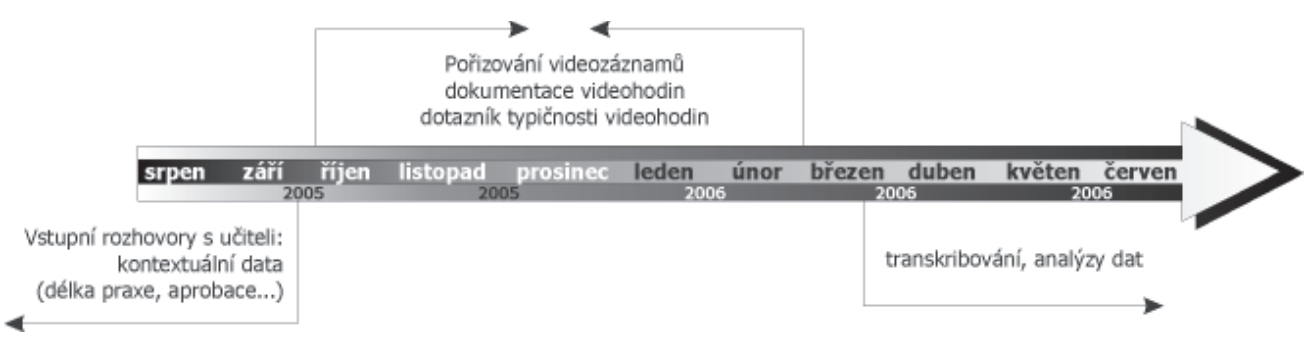

Obr. 1: Design CPV videostudie zeměpisu

Po navázání kontaktu se školami a učiteli, byly stanoveny termíny natáčení jednotlivých hodin. Výuku zeměpisu jsme nahrávali standardizovaným postupem

11 Nejčastější důvody odmítnutí, které učitelé uváděli, bylo značné pracovní vytížení související s tvorbou školního vzdělávacího programu a obava z př́tomnosti kamer ve výuce. 
(Janík, Miková 2006). Zaškolení kameramani natáčeli výuku podle předem stanovených pravidel, aby se získaná data mohla zpracovat, vyhodnotit, interpretovat a systematicky porovnávat. K natáčení se využívalo dvou videokamer. První kamera (žákovská) byla umístěna na stativu vedle tabule tak, aby zabírala celkové dění ve třídě. Druhá kamera (učitelská) byla $v$ rukou zaškoleného kameramana a zabírala učitele a zónu jeho bezprostřední interakce se žáky. Souběžně s pořizováním videozáznamu byla formou dotazníku získávána další data potřebná pro popisnou statistiku vztahující se k jednotlivým vyučovacím hodinám: téma vyučovací hodiny, aktuální počet žáků (z toho chlapců a dívek), používané mapy, učební pomůcky, domácí úkoly apod. Vedle toho byly distribuovány dotazníky autentičnosti pro jednotlivé učitele (Hübelová 2006).

Jak ukazuje tab. 1, zkoumaný soubor obsahuje celkem 5 škol, 6 tříd, 6 učitelů (z toho 5 žen a 1 muže) a 131 žáků. Všichni učitelé byli kvalifikovaní pro výuku zeměpisu na 2. stupni ZŠ nebo nižším ročníku gymnázia, přičemž převažovala kombinace zeměpisu s tělesnou výchovou. Délka jejich praxe se pohybovala v rozmezí od 2 do 17 let. Odlišnosti v počtech škol, tříd a učitelů jsou způsobeny tím, že v jedné ze škol byli nahráváni dva učitelé.

V průběhu školního roku 2005/06 bylo na druhém stupni základních škol a nižších ročníků gymnázií v Brně a blízkém okolí pořízeno 50 vyučovacích hodin zeměpisu k tématu „prírodní podmínky ČR". Skutečnost, že se téma probírá v rozdílných ročnících, je způsobena možností volby rozložení učiva. Stejně tak je rozdílná časová dotace $v$ jednotlivých ročnících. Nahrávky výuky učitele $D$ byly pořízeny místo $v$ osmém ročníku $v$ ročníku devátém. Vyplývalo to $z$ časově jinak rozvrženého tematického plánu školy.

\begin{tabular}{|c|c|c|c|c|c|c|c|}
\hline \multicolumn{3}{|c|}{ Učitel } & \multicolumn{2}{|r|}{ Žáci } & \multicolumn{3}{|c|}{ Učivo } \\
\hline $\begin{array}{l}\text { Kód } \\
\text { učitele }\end{array}$ & $\begin{array}{l}\text { Apro- } \\
\text { bace }\end{array}$ & $\begin{array}{l}\text { Délka } \\
\text { praxe }\end{array}$ & $\begin{array}{l}\text { Roč- } \\
\text { ník }\end{array}$ & \begin{tabular}{|c|} 
Počet \\
žáků \\
hoši/dívky
\end{tabular} & Téma & $\begin{array}{l}\text { Počet } \\
\text { hodin }\end{array}$ & Kódy hodin \\
\hline A & ZE - TV & 14 & 8. & $\begin{array}{c}20 \\
9 / 11\end{array}$ & $\begin{array}{c}\text { povrch, podnebí, } \\
\text { vodstvo, půdy, biota }\end{array}$ & 11 & $\begin{array}{l}\text { ZE_A1, ZE_A2, ZE_A3, } \\
\text { ZE_A4, ZE_A5, ZE_A6, } \\
\text { ZE_A7, ZE_A8, ZE_A9, } \\
\text { ZE_A10, ZE_A11 }\end{array}$ \\
\hline B & ZE - TV & 8 & 8. & $\begin{array}{c}29 \\
16 / 13\end{array}$ & $\begin{array}{l}\text { povrch, podnebí, } \\
\text { vodstvo }\end{array}$ & 8 & $\begin{array}{l}\text { ZE_B1, ZE_B2, ZE_B3, } \\
\text { ZE_B4, ZE_B5, ZE_B6, } \\
\text { ZE_B7, ZE_B8 }\end{array}$ \\
\hline$C$ & ZE - DĚ & 4 & 8. & $\begin{array}{c}22 \\
13 / 9\end{array}$ & $\begin{array}{c}\text { povrch, podnebí, } \\
\text { vodstvo, půdy, biota }\end{array}$ & 7 & $\begin{array}{l}\text { ZE_C1, ZE_C2, ZE_C3, } \\
\text { ZE_C4, ZE_C5, ZE_C6, } \\
\text { ZE_C7 }\end{array}$ \\
\hline D & ZE - MA & 10 & 9. & $\begin{array}{c}12 \\
8 / 4\end{array}$ & $\begin{array}{c}\text { povrch, podnebí, } \\
\text { vodstvo, půdy, biota }\end{array}$ & 6 & $\begin{array}{l}\text { ZE_D1, ZE_D2, ZE_D3, } \\
\text { ZE_D4, ZE_D5, ZE_D6 }\end{array}$ \\
\hline E & ZE - TV & 17 & 8. & $\begin{array}{c}31 \\
16 / 15\end{array}$ & $\begin{array}{c}\text { povrch, podnebí, } \\
\text { vodstvo, půdy, biota }\end{array}$ & 9 & $\begin{array}{l}\text { ZE_E1, ZE_E2, ZE_E3, } \\
\text { ZE_E4, ZE_E5, ZE_E6, } \\
\text { ZE_E7, ZE_E8, ZE_E9 }\end{array}$ \\
\hline
\end{tabular}




\begin{tabular}{|c|c|c|c|c|c|c|l|}
\hline F & ZE -TV & 2 & 8. & $\begin{array}{c}17 \\
8 / 9\end{array}$ & $\begin{array}{c}\text { povrch, podnebí, } \\
\text { vodstvo, půdy, biota }\end{array}$ & 9 & $\begin{array}{l}\text { ZE_F1,ZE_F2,ZE_F3, } \\
\text { ZE_F4,ZE_F5,ZE_F6, } \\
\text { ZE_F7,ZE_F8,ZE_F9 }\end{array}$ \\
\hline
\end{tabular}

Tab. 1: Popis zkoumaného souboru - CPV videostudie zeměpisu

\section{Do jaké míry byly zaznamenané hodiny autentické?}

V metodologických diskusích se často poukazuje na to, že vyučovací hodiny zaznamenávané na video nemusí zcela odpovídat tomu, jak výuka probíhá v běžných podmínkách - v nepř́tomnosti kamery. Uvádí se, že takové hodiny jsou zkreslené směrem k sociální „žádoucnosti“ (učitel předvádí „ideálni“ hodinu), nebo že jsou „nepovedené" právě kvưli př́tomnosti kamery (učitel je nervózní, žáci se „předváději"). Autentičnost zaznamenaných vyučovacích hodin byla sledována dotazníky, které byly učitelům distribuovány po skončení každé hodiny. Odpovědi (tab. 2) ukazují, že více než $90 \%$ zaznamenaných hodin učitelé označili jako typické nebo $z$ větší části typické, v $94 \%$ hodin se žáci podle učitele chovali velmi podobně nebo podobně jako v běžných hodinách a v $92 \%$ hodin se učitelé necítili vưbec nervózní nebo byli jen trochu nervózní. Domníváme se proto, že př́tomnost kamery průběh hodin spíše nenarušila. Vzhledem k tomu, že v CPV videostudii zeměpisu se natáčel obsáhlejší tematický celek (6-11 hodin u jednotlivých učitelů), Ize předpokládat, že díky delší prítomnosti kamer ve výuce měli učitelé i žáci možnost si alespoň částečně na kamery „zvyknout".

\begin{tabular}{lcc}
\hline & $\begin{array}{c}\text { Absolutní } \\
\text { četnost } \\
\mathrm{n}=50\end{array}$ & $\begin{array}{c}\text { Relativní } \\
\text { četnost }\end{array}$ \\
\hline Byla tato hodina typická ve srovnání s Vašimi obvyklými hodinami? & 18 & $36 \%$ \\
naprosto typická & 29 & $58 \%$ \\
z větší části typická & 2 & $4 \%$ \\
netypická & 1 & $2 \%$ \\
naprosto netypická & & \\
\hline Jak se v této hodině chovali žáci? & 30 & $60 \%$ \\
velmi podobně jako v běžných hodinách & 17 & $34 \%$ \\
podobně jako v běžných hodinách & 3 & $6 \%$ \\
trochu odlišně než v běžných hodinách & 0 & $0 \%$ \\
velmi odlišně od běžných hodin & & \\
\hline Do jaké míry jste byl(a) v této hodině nervózní? & 24 & $48 \%$ \\
vủbec nervózní & 6 & $12 \%$ \\
téměř vưbec nervózní & 16 & $32 \%$ \\
trochu nervózní & 4 & $8 \%$ \\
velmi nervózní & & \\
\hline
\end{tabular}

Tab. 2: Autenticita hodin zeměpisu zaznamenaných na video (podle výpovědí učitelů) 
Průměrná délka vyučovací hodiny v CPV videostudii zeměpisu byla 43:5012 minut, což téměř odpovídá běžně stanovené délce výuky. Nejdelší hodina trvala 46:30 minut. Nejkratší hodina trvala 38:00 minut. Ve zkoumaném souboru 50 videohodin byla výuka přerušena celkem čtrnáctkrát (např. přecházení žáků po zvonění v doprovodu učitele z kmenové třídy do specializované učebny, hlášení školního rozhlasu, pozdní př́chod učitele, který měl naléhavé jednání s rodiči, přerušování výuky příchodem rodičů v rámci dne otevřených dveří).

\subsection{Zpracování videozáznamů}

Prvním krokem po natočení hodiny je její převedení do počítače. Digitalizace je předpokladem pro počítačem podporovanou analýzu výzkumných dat.

Následujícím krokem bylo transkribování videozáznamů hodin. Transkripcí se v kontextu této práce rozumí přepisování zvukové části videozáznamu do psané podoby pomocí transkripčního systému a podle standardizovaného postupu (Seidel 2003; Janík, Miková 2006), aby všechny transkripty byly jednotné a vzájemně srovnatelné. V CPV videostudii zeměpisu probíhala transkripce videozáznamu v programu pro zpracování videozáznamu Videograph (Rimmele 2002).

Třetím krokem zpracování videozáznamu hodin bylo jejich kódování. Kódování je chápáno jako registrace jevů pozorovaných na videozáznamu do zadaného systému kategorií. Kategoriální systém, který byl vytvořený pro kódování videostudie fyziky na Institutu pro pedagogiku prírodních věd v Kielu (Seidel et al. 2003), byl přeložen a adaptován pro účely CPV videostudie fyziky (srov. Janík, Miková 2006) a po drobných úpravách využit ${ }^{13}$ také pro CPV videostudii zeměpisu (Hübelová 2006). Kategoriální systém postihuje dvě hlavní oblasti analýzy videozáznamů vyučovacích hodin: organizační formy výuky a fáze výuky. Kódovatele bylo třeba dostatečně zaškolit, aby pozorované jevy kódovali shodně, respektive dostatečně podobně. $\checkmark$ rámci kódování je třeba dosáhnout přijatelné míry inter-rater-reliability, tj. shody mezi jednotlivými kódovateli (Cohen's Kappa > 0,70; př́má shoda > 85 \%). V CPV videostudii zeměpisu bylo docíleno míry inter-rater-reliability v uvedených mezích.

\section{Výsledky videostudie - pohledy na výuku zeměpisu}

V této části příspěvku prezentujeme výsledky dílčích analýz. Předkládáme pohledy na organizační formy výuky (4.1), na fáze výuky (4.2), na vztahy fází a forem výuky (4.3) a na príležitosti k verbálnímu projevu (4.4).

12 Časové údaje u jednotlivých kategorií jsou uváděny ve formátu minuty:sekundy - např. 14:27, což znamená 14 minut a 27 sekund.

13 Nabízí se tak možnost určitého porovnání výsledků, které umožní hledat vzájemné podobnosti a odlišnosti napřič jednotlivými vyučovacími předměty základního vzdělávání. 


\subsection{Pohled na organizační formy výuky}

\section{V jakých organizačních formách se výuka odehrává?}

Organizační formy výuky jsou klíčovým prvkem ve struktuře vyučovací hodiny. Organizační formy výuky se vztahují k tomu, jak jsou ve výuce uspořádány podmínky pro realizaci vzdělávacího obsahu (srov. Maňák 2003). V jakých organizačních formách a v jakých časových proporcích se odehrávala sledovaná výuka je možné vyčíst z grafu 1.

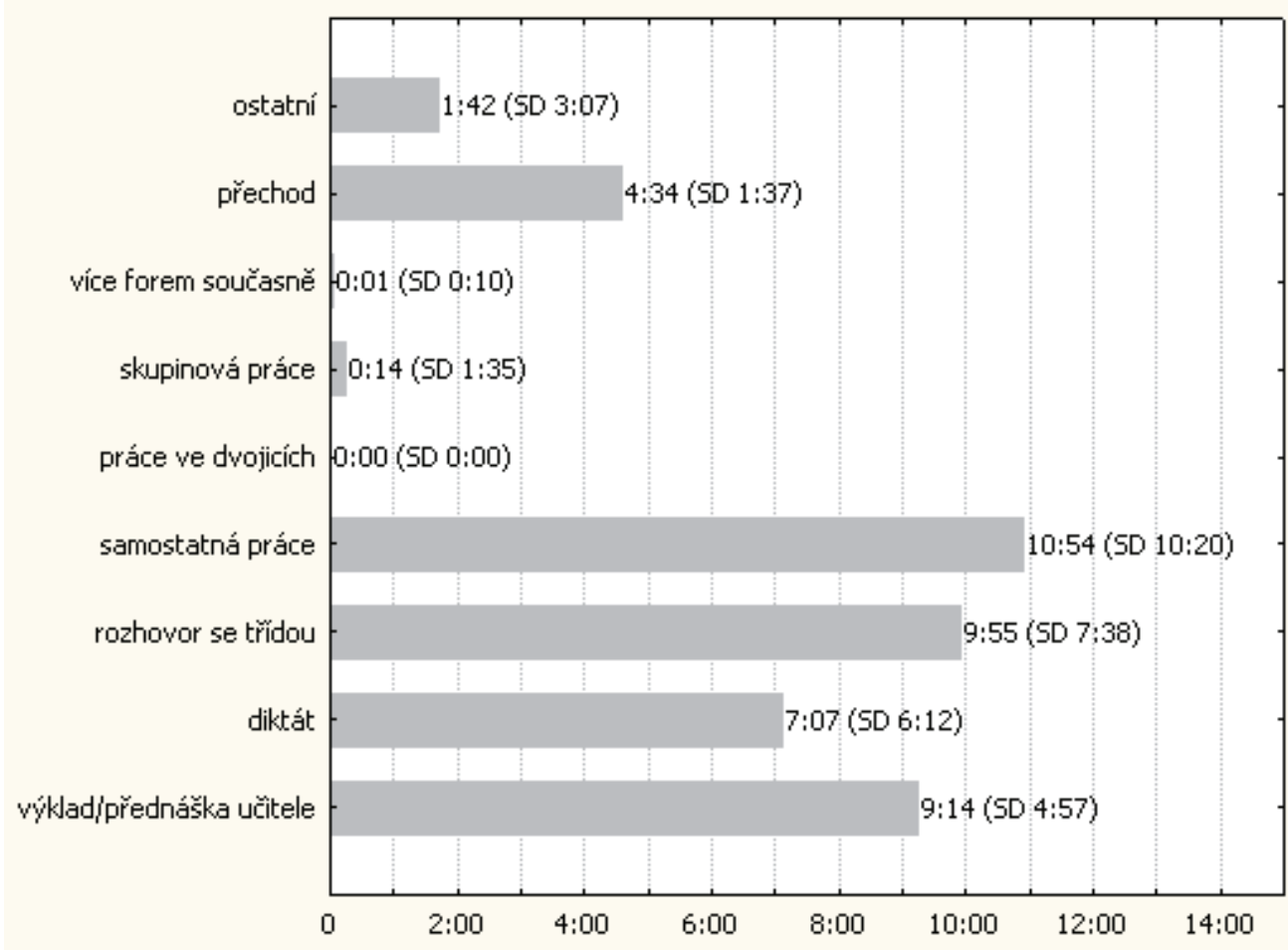

Graf 1: Průměrné časové rozložení organizačních forem

Analýzy ukázaly, že dominantní organizační formou výuky zeměpisu byla samostatná práce žáků, které bylo věnováno průměrně 10:54 minut. Jedná se o formu výuky, kdy vstupuje do popředí aktivita žáků, což je důležitý faktor pro další rozvoj znalostí a dovedností žákủ. Rozložení časového zastoupení v rámci jednotlivých hodin je však nerovnoměrné. $V$ hodinách, kdy žáci využívali výukový počítačový program, řešili otázky v pracovních listech nebo probíhalo jejich zkoušení formou didaktického testu, bylo zastoupení samostatné práce žákủ výrazné. V hodinách, kde se učitel věnoval především zpracování nového učiva, se naopak samostatná práce žáků téměř neobjevila.

$\checkmark$ celkovém hodnocení 50 vyučovacích hodin připadalo průměrně 9:55 minut výukového času na rozhovor se třídou. Ve zkoumaném souboru je i několik hodin, v nichž otázky učitelů nenacházely u žáků žádnou odezvu, takže učitelův pokus 
vést rozhovor se trídou postupně přecházel do formy výkladu/přednášky/instrukce. Pozastavíme-li se nad povahou otázek, které učitel žákům kladl, shledáme mezi jednotlivými učiteli značné rozdíly. Přestože např. učitel C věnoval v průměru 44,9\% výukového času rozhovoru, kladl uzavřené a reproduktivní otázky. Žáci pouze reprodukovali naučené a jejich vlastní komunikační aktivita byla nepatrná. Naopak učitel A, který vedl rozhovor se tř́dou jen v 15,1\% výukového času, přesto nabízel žákům př́ležitosti pro bohatší odpovědi a poskytoval jim zpětnou vazbu, což můžeme z velké části považovat za rozhovor intencionální (srov. Šed’ová 2005). Přestože ne všechny odpovědi žáků zcela souvisely s učivem, dokázal učitel zpravidla udržet vazbu s probíraným tématem.

Dále byla ve výuce zeměpisu výrazně zastoupena forma výklad/přednáška/instrukce, které učitelé věnovali průměrně 9:14 minut. Činnost učitele, která se orientovala na metodu vysvětlování (výklad/přednáška/instrukce), byla často vázána na frontální výuku, a to především v souvislosti se zpracováním nového učiva. Vzhledem k obsahové náročnosti učiva zeměpisu byla tato kategorie zastoupena rovnoměrně prakticky ve všech zkoumaných hodinách. Výklad umožňoval také učivo shrnout a uspořádat. Přednášku mohl představovat také žákovský referát, tuto organizační formu výuky (referát) volil jako jediný učitel F.

Organizační forma diktát byla zastoupena 7:07 minutami. Jednalo se především o diktování či opisování zápisu žáky do sešitu a tato aktivita byla situována zpravidla v druhé části vyučovací hodiny. Diktát nepředstavuje aktivní zapojení (ve smyslu kognitivní angažovanosti) žáků ve výuce. Projevila se patrná rozdílnost v časovém zastoupení této organizační formy u učitelů, kteří diktovali žákům zápis, a u učitelů, kteř́ měli zápis připravený na fólii (zpětný projektor) nebo v digitální podobě (dataprojektor), přestože množství takto zapsaného učiva do sešitů je srovnatelné. Výsledky ukázaly, že učitelé, kteři žákům zápis diktovali, strávili touto formou více výukového času, souhrnně přes pětinu doby vyučovací hodiny.

Skupinová práce se $v$ celkových časových proporcích vyskytovala jen 0:14 minut. Ve zkoumané výuce se souhrnně projevuje velmi malé zastoupení kategorií podporujících aktivitu a kooperaci žáků - práce ve dvojicích (0:00 minut) a práce ve skupinách (0:14 minut). Minimální časové zastoupení kategorie více forem současně (0:01 minut) ukazuje, že učitelé volili organizačně méně náročné formy výuky.

Na organizační záležitosti, které jsou představovány např. zápisem do třídní knihy, prípravou atlasů nebo nástěnných map a spadají do kategorie přechod, připadalo 4:34 minut. Kategorie ostatní zahrnovala takové situace ve výuce, které nebylo možno přiřadit do žádné $z$ výše uvedených organizačních forem, a byla časově zastoupena 1:42 minut. Do fáze ostatní spadaly především situace, kdy byl učitel nucen řešit kázeňské přestupky a problémy, jako bylo např. vyrušování ve výuce. $V$ časovém zastoupení kategorie ostatní u jednotlivých učitelů Ize vypozorovat značnou rozdílnost podle jejich schopností zvládat kázeňské problémy a udržet si pozornost žáků.

\section{Je výuka zeměpisu více orientovaná na učitele nebo na žáky?}

V souvislosti s analýzou organizačních forem nás zajímalo, zda je sledovaná výuka orientovaná spíše na učitele nebo na žáky. Jak je patrné z tab. 3 a grafu 2, zastou- 
pení forem orientovaných na žáky není ve výuce přiliš vysoké. Organizační formy orientované na učitele zahrnují v průměru 26:15 minut, zatímco formy orientované na žáky v průměru jen 11:09 minut.

\begin{tabular}{|l|c|c|}
\cline { 2 - 3 } \multicolumn{1}{c|}{} & Průměr & SD \\
\hline Organizační formy orientované na učitele & $26: 15$ & $10: 52$ \\
\hline Organizační formy orientované na žáky & $11: 09$ & $10: 14$ \\
\hline
\end{tabular}

Tab. 3: Orientace organizačních forem výuky

(průměrný čas v minutách za vyučovací hodinu)

Kritéria pro určení typologie vyučovacích hodin, která byla vytvořena v CPV videostudii fyziky (Janík, Miková 2006, s. 91), jsme převzali za účelem porovnání také pro CPV videostudii zeměpisu. Pro představu o rozložení forem orientovaných na učitele a forem orientovaných na žáky představujeme typologii vyučovacích hodin, ve které figurují dva typy:

- Hodina orientovaná na učitele, v níž převládá podíl forem, ve kterých vystupuje do popředí učitel (výklad/přednáška/instrukce, diktát, rozhovor se třídou ${ }^{14}$ ) a je vyšší než $1 \frac{1}{2}$ času věnovaného práci s učivem.

- Hodina orientovaná na žáky, v níž převládá podíl forem, ve kterých vystupují do popředí žáci (samostatná práce, práce ve dvojicích, práce ve skupinách a více forem současně) a je vyšší než $1 \frac{1}{2}$ času věnovaného práci s učivem.

$V$ souboru 50 hodin výuky zeměpisu převažovaly $v 41$ hodině organizační formy orientované na učitele a v 9 hodinách formy orientované na žáky. Rozvrstvení hodin výuky zeměpisu podle zmíněné typologie je orientační, nebot' má svá omezení. $\checkmark$ hodinách, kde bylo prezentováno nové učivo učitelem, byly více zastoupeny organizační formy orientované na učitele. Naopak v hodinách, ve kterých převládala samostatná práce, byly zastoupeny formy orientované na žáky. Týká se to především závěrečné vyučovací hodiny, kterou bylo u všech učitelů (kromě učitele D) zakončeno téma "prírodní podmínky České republiky“ formou didaktického testu. $V$ hodinách učitele $A$ (ZE_A5, ZE_A6, ZE_A9), které probíhaly v počítačové učebně a byly zaměřeny na procvičování lokalizace zeměpisných objektů pomocí počítačového výukového programu, výrazně převládal podíl forem, ve kterých vystupovali do popředí žáci.

Převaha forem orientovaných na učitele se ukázala u všech sledovaných učitelů alespoň v jedné ze zkoumaných hodin. Je patrné, že pět z šesti zkoumaných hodin učitele $C$ bylo orientovaných na učitele, z toho tři hodiny se $100 \%$ zastoupením forem orientovaných na učitele.

Přes svá omezení mohou zjištěné proporce mezi formami orientovanými na učitele a formami orientovanými na žáky ukazovat na nízkou aktivitu žáků ve výuce zeměpisu. Výrazně se orientují na poslouchání, a to především ve fázi zpracování nového učiva.

14 Rozhovor se třídou sice probíhá jako vzájemná interakce učitele a žáka/žáků, neřadíme ho však mezi formy orientované na žáky. Důvodem je fakt, že tento rozhovor je v naprosté většině případů určován učitelem. 


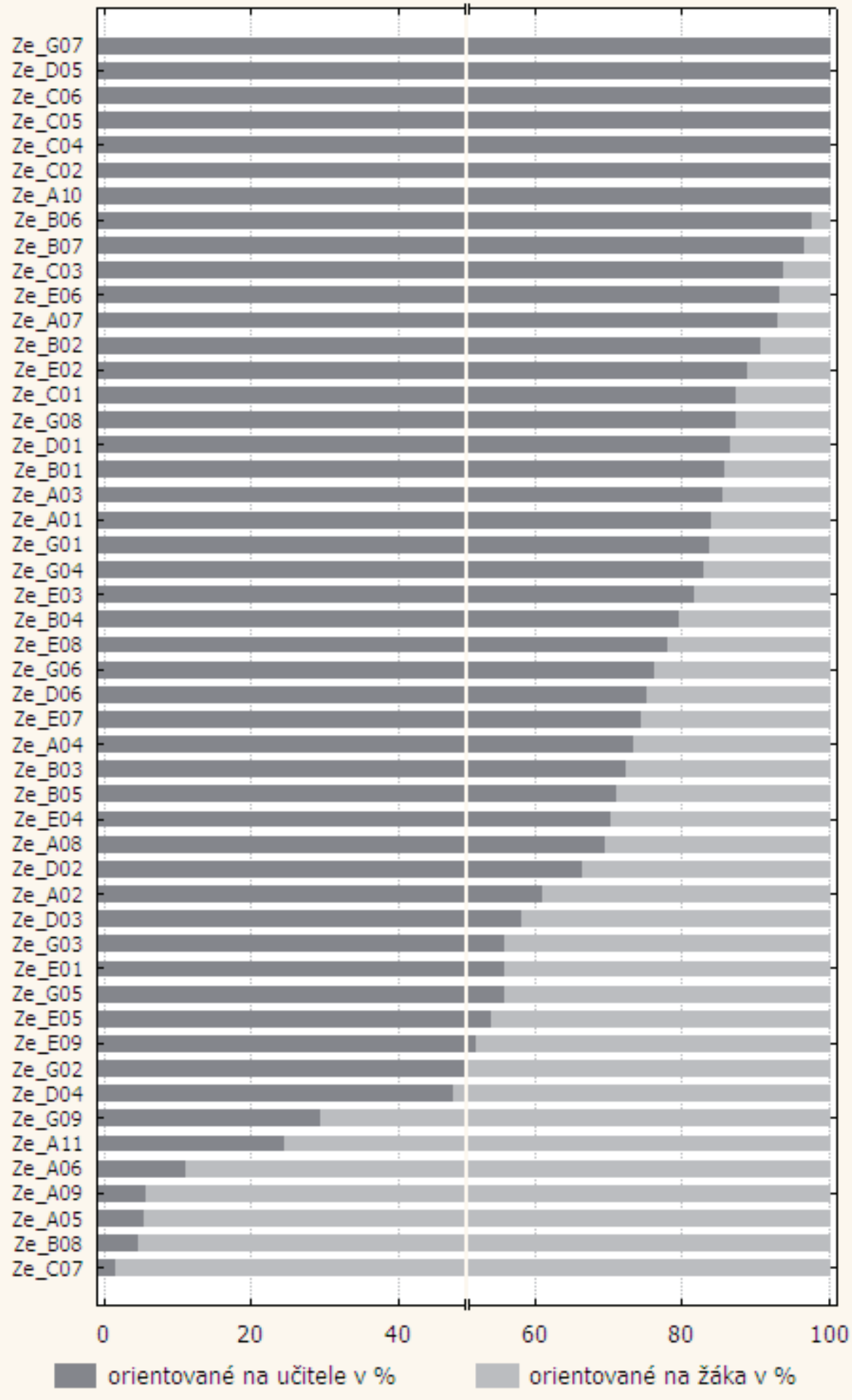

Graf 2: Orientace forem výuky v jednotlivých hodinách 


\subsection{Pohled na fáze výuky}

\section{V jakých fázích se výuka odehrává?}

Didaktická kategorie fáze výuky se vztahuje k procesuální stránce výuky. Jak uvádí J. Maňák (2003, s. 26), fáze výuky člení „proces výuky na určité sekvence, které však neIze chápat jako izolované a uzavřené časové úseky, nýbrž jako variabilní momenty výuky, které nutně každá výuka i každý typ výuky v sobě obsahuje". Z grafu 3 je možné vyčíst, $v$ jakých fázích a v jakém časovém zastoupení se odehrávala sledovaná výuka 50 hodin CPV videostudie zeměpisu.

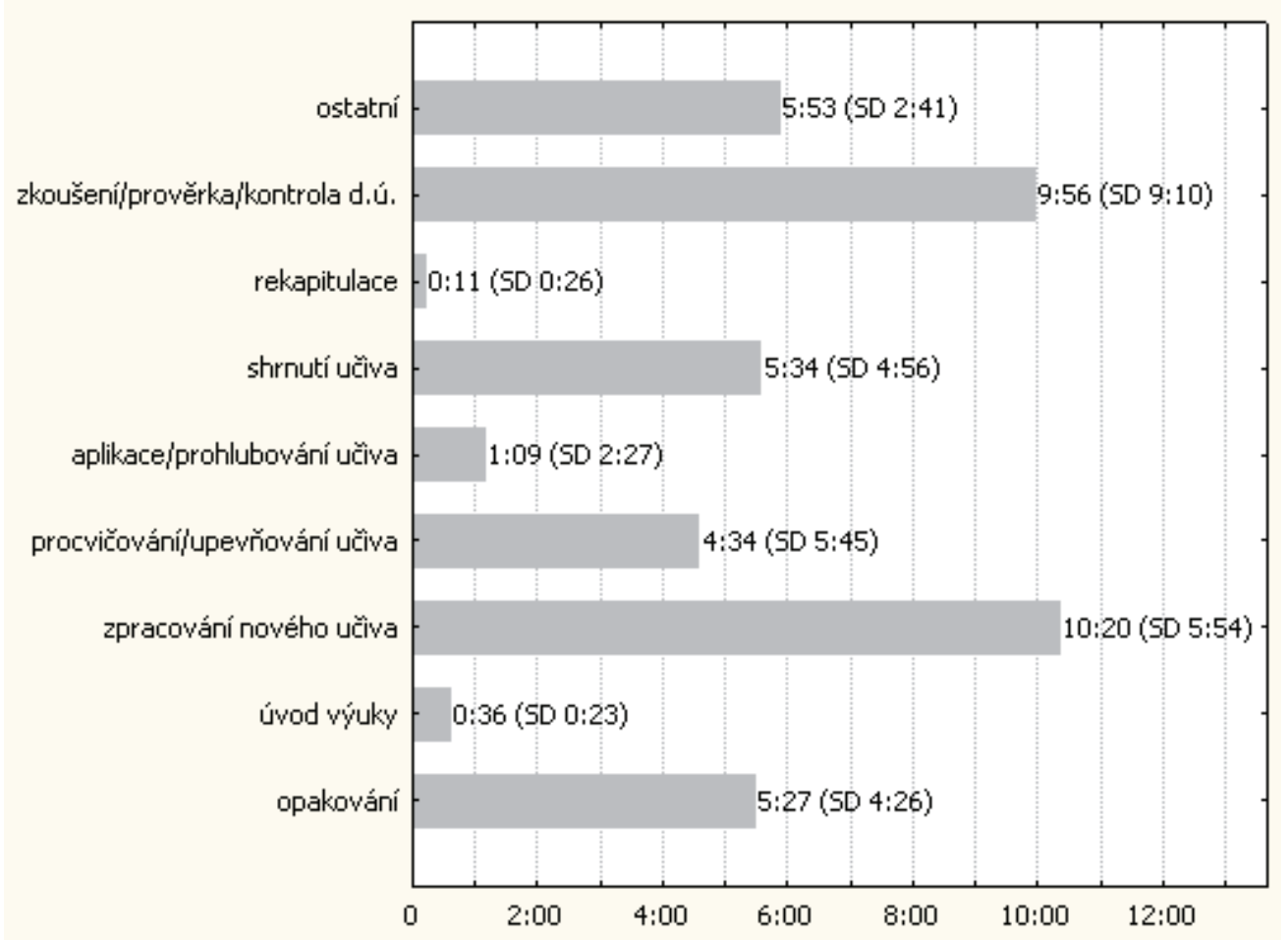

Graf 3: Průměrné časové rozložení fází výuky

Mezi zkoumanými hodinami jsou patrné odlišnosti v časovém zastoupení jednotlivých fází výuky (graf 3). Průměrně učitelé věnovali nejvíce času fázi zprostředkování nového učiva (10:20 minut), at se odehrávala formou výkladu nebo formou rozhovoru se žáky. Kategorie zprostředkování nového učiva převládala ve většině zkoumaných hodin ${ }^{15}$.

Fáze zkoušení/prověrka/kontrola domácího úkolu zabírala jako druhá největší prostor výukového času (9:56 minut). Těžiště této kategorie spočívalo ve zkoušení

15 Výjimku představovaly ty hodiny, kterými byl ukončen tematický celek o prírodních podmínkách České republiky formou didaktického testu. Učitel A, pokud měli žáci možnost výuky v počítačové učebně, věnoval tuto výuku procvičování učiva. 
žáka/žáků před tabulí. Zkoušení ve většině případů probíhalo ústní formou. Písemné zkoušení se uskutečnilo ve sledovaných třídách až na závěr tematického celku. Zadané domácí úkoly byly kontrolovány na začátku hodiny, byla ověřována správnost řešení, a to vždy formou rozhovoru se třídou.

Třetí časově nejvíce zastoupenou fází bylo shrnutí učiva, $\mathrm{k}$ němuž se řadí především pořizení zápisu žáky o právě probraném učivu do sešitů. Vzhledem $\mathrm{k}$ tomu, že $v$ každé sledované hodině si žáci zapisovali shrnutí učiva ve formě i poměrně obsáhlých zápisů do sešitu, bylo časové zastoupení shrnutí učiva 5:34 minut. Shrnutí učiva má za cíl připomenout a utřídit učivo, žáci využívali dobu zápisu do sešitů $\mathrm{k}$ př́padným dotazům $\mathrm{k}$ právě probranému učivu.

Fázi opakování bylo ve výuce zeměpisu věnováno 5:27 minut, jejím cílem bylo připomenout a aktualizovat již získané znalosti. Vzhledem k výrazné obsahové propojenosti učiva zeměpisu od roviny obecné po konkrétní a naopak, je průměrné časové zastoupení fáze opakování legitimní. Výrazné jsou časové rozdíly věnované fázi opakování mezi jednotlivými učiteli (7,1 \% výukového času u učitele A - 21,4\% výukového času u učitele D).

Fáze procvičování/upevňování učiva byla zastoupena v 4:34 minutách. Úkoly pro procvičování byly často zadávány formou domácí přípravy žáků, tudíž se v následující vyučovací hodině vyskytovaly ve fázi zkoušení/prověrka/kontrola domácího úkolu právě jako kontrola domácího úkolu. Čas věnovaný procvičování/ upevňování učiva se opět u jednotlivých učitelů značně lišil, a to v rozpětí od $19,7 \%$ (učitel A) po 3,7\% (učitel E) výukového času.

Časové zastoupení fáze aplikace/prohlubování bylo 1:09 minut. Také fáze úvod výuky (0:34 minut) a fáze rekapitulace učiva (0:11 minut) byly zastoupeny relativně krátkým časovým úsekem. Do kategorie úvod výuky byla při kódování zařazována také motivační část výuky. Ve fázi rekapitulace učiva by měla být věnována pozornost tomu, , jak se učilo". Rekapitulace je chápána jako opakování, které se nezaměřuje na obsah, nýbrž reflektuje proběhnuvší pracovní či učební proces (Aebli 2003, s. 368). Zastoupení této fáze bylo 0:11 minut.

Kategorie ostatní zahrnovala situace, které nebylo možno řadit do žádné z uvedených kategorií, a byla zastoupena v 5:53 minutách. Do této fáze byly zařazeny části výuky, které nesouvisely s učivem. Jednalo se především o řešení organizačních záležitostí a situací, kdy byl učitel nucen výuku přerušit při řešení kázeňských a jiných problémů. Opět bylo možné vysledovat značné rozdíly mezi jednotlivými učiteli a to $v$ rozpětí od $8,4 \%$ (učitel F) až po $22,8 \%$ (učitel B). Tyto rozdíly odrážely schopnost udržet ve výuce kázeň. 


\subsection{Pohled na vztah mezi organizačními formami a fázemi}

\section{Jak spolu souvisejí výukové fáze a organizační formy?}

Zkoumání a určení vztahů mezi organizačními formami a fázemi výuky umožnilo provést detailní rozbor struktury vyučovacích hodin zeměpisu (tab. 4). Tato vztahová analýza představuje možnost postihnout souhru působení jednotlivých faktorů ve výuce. Smyslem analýzy bylo odpovědět na otázku, jaké organizační formy se uplatňují v jednotlivých fázích?

Fáze opakování se ve sledované výuce objevovala obvykle na začátku vyučovací hodiny. Opakování se téměř vždy odehrávalo formou rozhovoru se třídou (59\%), který byl iniciován učitelem a měl za cíl aktualizovat učivo, které už žáci probírali. $\checkmark$ druhém případě se fáze opakování prolínala s formou výklad/přednáška/instrukce učitele (31\%), kdy se učitel odvolával na již probrané učivo, které souviselo s novou látkou. Shodně se na fázi opakování podílely také organizační formy diktát a samostatná práce, v obou případech po $5 \%$.

Ve fázi úvod výuky sehrával hlavní roli učitel, který žákům obvykle oznámil téma hodiny a eventuelně velmi stručně popsal, jaké učivo se bude probírat a co bude náplní hodiny z hlediska metodického. Úvod výuky měl v drtivé většině prípadů podobu výkladu/přednášky/instrukce učitele (97\%). Jen ve $2 \%$ se odehrával formou rozhovoru se třídou a pouze v $1 \%$ jako diktát. Analýza transkriptů ukázala, že až na několik málo výjimek neobsahovala fáze úvod výuky motivaci žáků k učení.

Ve fázi zprostredkování nového učiva přebíral ve většině př́ipadů zodpovědnost učitel. Ten podával výklad/přednášku/instrukci k učivu (v $52 \%$ ), aniž by mu do něj žáci mohli vstupovat. Druhou nejvíce zastoupenou formou byl rozhovor se třídou ( $222 \%)$, který ŕídil učitel a v němž bylo vyvozováno učivo. Žáci se dostali ke slovu zpravidla jen v rámci uzavřených otázek, které jim učitel kladl, nebo žáci doplňovali učitelovy nedokončené věty. Výjimečně se objevily i situace, kdy žáci při formě rozhovoru se třídou vznesli otázky, se kterými se dále pracovalo - zpravidla pouze pokud byly "k věci“. V $16 \%$ bylo nové učivo zprostředkováváno formou diktátu. $\checkmark$ případě $8 \%$ museli žáci vyvozovat nové učivo formou samostatné práce a formou práce ve skupinách ve $2 \%$.

Ve sledované výuce se fáze procvičování/upevňování učiva zpravidla odehrávala prostřednictvím řešení úloh formou samostatné práce žáků (v 61 \%). Učivo bylo také procvičováno formou rozhovoru se trídou (v 31 \%), v menší míře pak formou výkladu/přednášky (v $6 \%$ ) nebo diktátu (ve $2 \%$ ). V žádné z hodin nebyla fáze procvičování/upevňování organizována formou práce ve dvojicích nebo práce ve skupinách.

Ve fázi aplikace/prohlubování učiva převažovala forma rozhovoru se třídou (v $57 \%$ ) a výkladu/přednášky/instrukce učitele (ve 32 \%). Obvykle měla podobu aplikování teoretické obsahové stránky učiva do reálného života a prostředí. Dále se tato fáze odehrávala ve formě samostatné práce (v $8 \%$ ) a také ve formě více forem současně (2\%). V malé míre se uplatnila ve formě diktát (1\%). Fáze aplikace/prohlubování učiva 


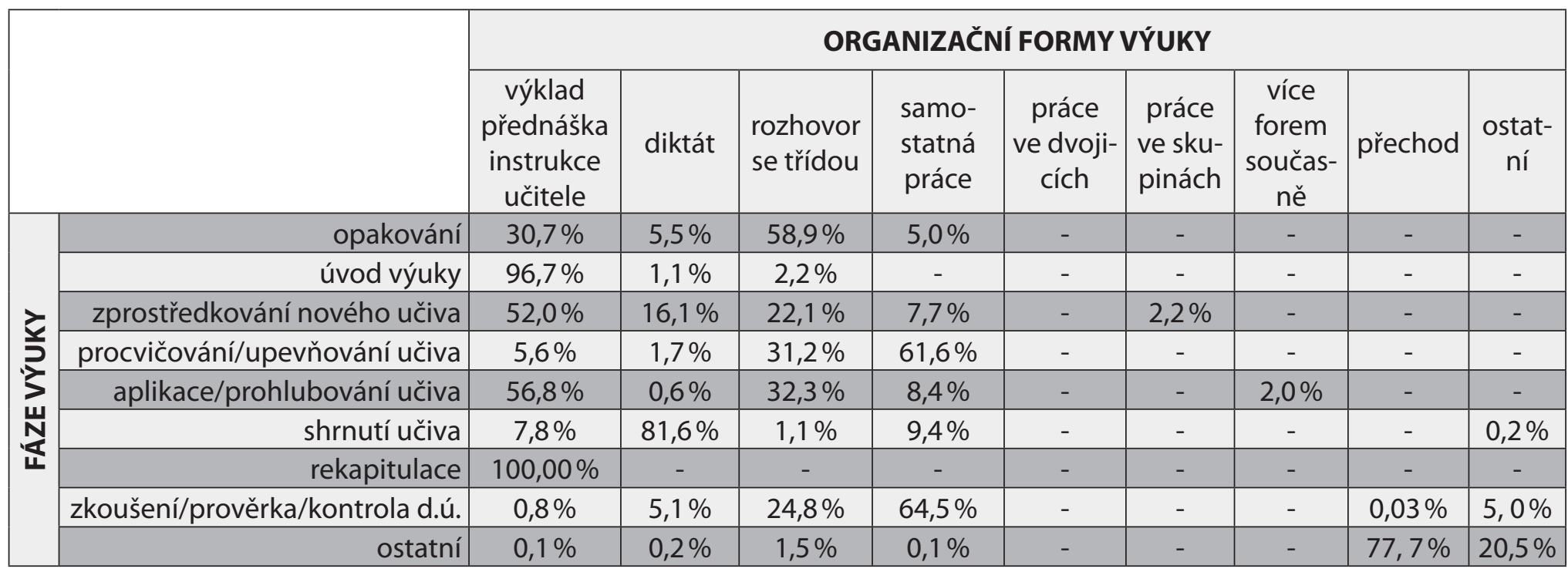

Tab. 4: Vztahy mezi fázemi a organizačními formami výuky 
se od fáze procvičování/upevňování učiva odlišovala v tom, že žáci uplatňovali učivo při řešení praktických úloh a v problémových kontextech.

Fáze shrnutí učiva byla realizována nejčastěji formou diktátu (v $82 \%)$.V ostatních formách byla rovnoměrně rozložena mezi samostatnou práci $(9 \%)$ a výklad učitele (8\%) a jen v $1 \%$ se objevila jako rozhovor se tř́dou. Hlavní náplní této fáze bylo především žákovské opisování zápisu (z tabule, zpětného projektoru, dataprojektoru) nebo diktování zápisu učitelem v průběhu prezentace nového učiva.

Fáze rekapitulace ve většině zkoumaných hodin chyběla. Pokud se objevila, byla realizována učitelem, a to vždy formou výkladu/přednášky/instrukce (ve $100 \%$ ).

Fáze zkoušení/prověrka/kontrola domácího úkolu nabízí učiteli možnost diagnostikovat a hodnotit výkony svých žáků, ústní nebo písemné zkoušení skýtá prostor pro projevy žáků. Tato fáze se zpravidla odehrávala formou samostatné práce (v $64 \%$ ). Většina učitelů totiž využívala čas ústního zkoušení jednoho žáka u tabule k zadání úloh pro ostatní žáky. Většinová aktivita žáků ve třídě pak probíhala formou samostatné práce. Ve fázi zkoušení/prověrka/kontrola domácího úkolu se dále uplatňovala forma rozhovoru se třídou ( $v 25 \%$ ), kdy se do zkoušení jednoho žáka snažil učitel zapojit širší okruh žáků, což se mu v některých případech př́liš nedařilo a zkoušení bylo do značné míry narušováno nekázní třídy. Také z tohoto důvodu se fáze zkoušení/prověrka/kontrola domácího úkolu realizuje v $5 \%$ ve formě ostatní. $\checkmark$ malé míre byla zastoupena forma diktátu (5\%) a výkladu/přednášky/instrukce učitele (1\%), a to zejména v rámci kontroly domácích úkolů.

Fáze ostatní se týkala převážně organizačních záležitostí, které přímo nesouvisely s učivem. Tato fáze byla spojována $v$ převaze všech prípadů s formou přechod $(78 \%)$, ostatní (20\%) a v malé míre jako rozhovor se trí́dou (2\%).

\subsection{Pohled na příležitosti k verbálnímu projevu}

Jednou z oblastí zájmu CPV videostudie zeměpisu bylo zkoumání príležitostí k verbálnímu projevu ve výuce. Při této analýze byly vyhodnoceny transkripty všech 50 vyučovacích hodin zeměpisu. Pro každou vyučovací hodinu jsme vypočítali celkový počet slov, dále počet slov učitele a počet slov všech žáků dohromady při veřejné interakci. Počet slov učitele se následně dělil počtem slov všech žáků ve třídě, čímž byl získán údaj o proporcích verbálních projevů učitele a žáků v jednotlivých hodinách. Výsledky této analýzy ukazují, že hlavní slovo ve výuce má učitel. Průměrný počet slov učitele ve vyučovací hodině činí 2807 . Průměrný počet slov žákư ve vyučovací hodině činí 474 . Poměr verbálních projevů učitele oproti verbálním projevům všech žáků ve třídě dohromady dosahuje hodnoty 5,92. To znamená, že učitel hovoří v hodině téměř šestkrát více než všichni žáci dohromady.

Mezi jednotlivými hodinami a objemy verbálního projevu učitelů a žáků existují individuální odlišnosti. Nejníže skórovaly čtyři vyučovací hodiny učitele C (ZE_C1, ZE_C2, ZE_C3, ZE_C5) a jedna hodina u učitele $F$ (ZE_F3), kdy byl poměr príležitostí $k$ verbálnímu projevu 3:1. Nejvýše naopak skórovala vyučovací hodina učitele $F$ (ZE_F8), ve které byla komunikační převaha učitele dvacetinásobná. Taková komunikační prevaha byla nalezena pouze v jedné ze všech 50 videohodin zeměpisu. 


\section{Jsou patrné rozdíly v objemu verbálního projevu u jednotlivých učitelů?}

Vzhledem k tomu, že v CPV videostudii zeměpisu byly pořizeny videozáznamy 6-11 hodin výuky zeměpisu téhož tematického celku, bylo možné přistoupit $k$ jejich vzájemnému srovnání. Na základě analýzy transkriptů Ize sledované učitele charakterizovat ve vztahu k jejich komunikaci. Objem verbálního projevu jednotlivých učitelů a žáků jsou uvedeny v tab. 5.

\begin{tabular}{|c|c|c|c|c|}
\hline Kód & $\begin{array}{c}\text { Počet slov } \\
\text { celkem } \\
\text { za vyučovací } \\
\text { hodinu }\end{array}$ & $\begin{array}{c}\text { Počet slov } \\
\text { učitele } \\
\text { za vyučovací } \\
\text { hodinu }\end{array}$ & $\begin{array}{c}\text { Počet slov } \\
\text { žáků } \\
\text { za vyučovací } \\
\text { hodinu }\end{array}$ & $\begin{array}{c}\text { Příležitosti } \\
\text { k verbálnímu projevu } \\
\text { učitel : žáci }\end{array}$ \\
\hline A & 3366 & 2876 & 490 & $6: 1(5,81)$ \\
\hline B & 3955 & 3509 & 446 & $8: 1(7,88)$ \\
\hline C & 2949 & 2303 & 646 & $4: 1(3,57)$ \\
\hline D & 3552 & 3142 & 410 & $8: 1(7,66)$ \\
\hline E & 3145 & 2648 & 497 & $5: 1(5,33)$ \\
\hline F & 2717 & 2364 & 353 & $7: 1(6,70)$ \\
\hline
\end{tabular}

Tab. 5: Průměrný počet slov a porovnání př́ležitostí k verbálnímu projevu

Učitel $A$ hovořil ve výuce průměrně šestkrát více než všichni žáci dohromady. $Z$ transkriptů je patrné, že učitel $A$ umožňoval žákům $v$ některých prípadech „více mluvit". Dokázal klást otevřené otázky a ptal se žáků na jejich vlastní názory a zkušenosti takovým způsobem, že udržel tematický obsah výuky. Učitel B hovořil ve výuce osmkrát více než všichni žáci dohromady. Obsahová stránka výuky měla často formální charakter, učitel volil k výkladu podstatné učivo, které však mělo obvykle popisný charakter. Žáci měli možnost souvislejšího slovního projevu jen $v$ rámci zkoušení, nebot $v$ ostatních případech učitel obvykle kladl uzavřené otázky s možností jednoslovné odpovědi nebo žáci jen doplňovali nedokončené věty učitele. Snaha učitele o využití metody rozhovoru v mnoha př́padech narážela na nezájem a pasivitu ze strany žáků. Značný objem žákovské konverzace byl veden mimo obsah výuky (žáci se omlouvali, učitel napomínal atp.). Komunikační převaha učitele C oproti žákům byla nejnižší, a to 4:1. Nejčastěji využívanou organizační formou byl rozhovor se třídou, a to i v př́padě zprostředkování nového učiva. Otázky učitele $v$ drtivé většině př́ipadů vyžadovaly jen jednoslovné či dvouslovné odpovědi žáků nebo představovaly doplnění učitelovy věty. Otázky kladené učitelem byly stereotypní, jejich znění se neustále opakovalo. Ve výuce učitele $D$ byl zaznamenán poměr príležitostí k verbálnímu projevu učitele a žáků 8:1. Přestože se učitel snažil podporovat slovní projevy žáků (,ukazuj a povídej"), žáci se často uchylovali k jednoslovným nebo dvouslovným odpovědím. Ve výuce neprobíhalo „klasické“ zkoušení žáků u tabule. Pozitivním jevem ve výuce učitele $D$ je skutečnost, že dokázal precizně pracovat $s$ jazykovou komunikací, vhodně používal a pracoval se slovy a mateřským jazykem. Komunikační převaha učitele E byla nižší (5:1) než uvedený celkový průměr objemu verbálního projevu ve videohodinách zeměpisu. Učitel $\mathrm{E}$ 
se velmi podrobně věnoval obsahu učiva, přesto byl výklad stručný a přehledný. Při opakování a procvičování učiva vyžadoval učitel od žáků samostatné vyjádření zeměpisných souvislostí, nejednalo se jen o reprodukci učiva. Učitel F hovořil ve výuce zeměpisu sedmkrát více než všichni žáci dohromady. Při výkladu nového učiva postupoval učitel $\mathrm{F}$ velmi stručně, zbytečně neodbíhal od probíraného tématu, hovořil „,k věci“. Žáci měli možnost souvislejšího slovního projevu jen v rámci zkoušení, nebot' učitel obvykle kladl př́liš uzavřené otázky s možností výběru odpovědi nebo možností jednoslovné odpovědi (např. „Pro zemědělství jsou vhodné nižiny nebo vysočiny?").

\section{Přiležitosti k verbálnímu projevu v různých výukových tématech}

Nepotvrdil se předpoklad, že jednotlivá témata výuky se budou shodovat nebo alespoň podobat co do množství verbálních projevů učitele a žáků vzhledem $\mathrm{k}$ obsahu učiva. Pro ilustraci předkládáme porovnání poměrů príležitostí verbálního projevu ve dvou výukových tématech (tab. 6).

\begin{tabular}{|c|c|c|}
\hline Kód & Téma výuky & $\begin{array}{c}\text { Poměr příležitostí } \\
\text { k verbálnímu projevu } \\
\text { učitel : žáci }\end{array}$ \\
\hline ZE_A8 & \multirow{9}{*}{ vodstvo ČR } & $6: 1$ \\
\hline ZE_B4 & & $9: 1$ \\
\hline ZE_C2 & & $3: 1$ \\
\hline ZE_C3 & & $3: 1$ \\
\hline ZE_D6 & & $9: 1$ \\
\hline ZE_E1 & & $4: 1$ \\
\hline ZE_E2 & & $5: 1$ \\
\hline ZE_F6 & & $7: 1$ \\
\hline ZE_F7 & & $11: 1$ \\
\hline ZE_A7 & \multirow{7}{*}{ podnebí ČR } & $7: 1$ \\
\hline ZE_B3 & & $8: 1$ \\
\hline ZE_C1 & & $3: 1$ \\
\hline ZE_D4 & & $6: 1$ \\
\hline ZE_D5 & & $6: 1$ \\
\hline ZE_F4 & & $7: 1$ \\
\hline ZE_F5 & & $5: 1$ \\
\hline
\end{tabular}

Tab. 6: Porovnání príležitostí k verbálnímu projevu v různých výukových tématech

Pro téma "vodstvo České republiky" se objem přiležitostí k verbálnímu projevu učitele a žáků pohyboval od 3:1 u učitele C (hodina ZE_C2, ZE_C3) po 9:1 u učitele B (hodina ZE_B4) a 11:1 u učitele F (hodina ZE_F7). Pro téma „podnebí České republiky“ jsme zaznamenali nejnižší skóre opět $u$ učitele $C$, kdy byl poměr verbálních aktivit v hodině ZE_C1 vyčíslen na 3:1, nejvyšší skóre pak u učitele B s poměrem 8:1 ve prospěch učitele (hodina ZE_B3). 


\section{Shrnutí výsledků, diskuse, závěry}

Dominantní organizační formou výuky zeměpisu byla samostatná práce žáků (10:54 minut). Organizační forma rozhovor se třídou (9:55 minut) byla sice druhou nejvíce zastoupenou kategorií, ale ve shodě se zjištěním K. Šed’ové můžeme konstatovat, že ve výuce zeměpisu převládal rozhovor mající často povahu „iluzivního dialogu“ a v některých př́padech byl „obsahově vyprázdněný" (srov. Šed’ová 2005). Třetí organizační formou zastoupenou ve větší míre byla forma výkladu/přednášky/instrukce (9:14 minut). Ostatní organizační formy byly zastoupeny v menší míre. $\checkmark$ př́padě organizační formy diktát (7:07 minut) se jednalo především o diktování nebo pasivní opisování zápisu žáky do sešitu. Minimální časové zastoupení bylo pro práci ve skupinách (0:14 minut) a více forem současně (0:01 minut). Práce ve dvojicích se ve sledované výuce nevyskytovala.

Ve zkoumaných hodinách převládaly formy orientované na učitele (26:15 minut) nad formami orientovanými na žáky (11:09 minut) Mezi jednotlivými hodinami se však projevily výrazné odlišnosti v rozložení forem orientovaných na učitele a orientovaných na žáky.

Z analýzy 50 vyučovacích hodin zeměpisu je dále patrné, že důraz byl kladen především na expozici učiva (fáze zprostredkování nového učiva a to 10:20 minut). Jako dominantní se ukázala také fáze diagnostická - zkoušení/prověrka/kontrola domácího úkolu (9:56 minut). Relativně velké časové zastoupení měla fáze opakování (5:27 minut). Méně výukového času věnovali učitelé fázi procvičování/upevňování učiva (4:34 minut). Vysvětlením může být skutečnost, že úkoly pro procvičování byly často zadávány formou domácí úlohy. Ukázalo se, že některé $z$ fází se vyskytovaly ve výuce jen zřídka nebo byly zcela vynechány. Fáze aplikace/prohlubování učiva se objevila jen $v$ relativně malé míre (1:09 minut). Nízké bylo časové zastoupení fáze úvod do výuky (0:36 minut). Krátký výukový čas byl věnovaný také rekapitulaci učiva (0:11 minut), v níz se od učitelů očekává, že budou schopni fundovaně podporovat učební proces žáků.

Ukazuje se, že ve zkoumaných hodinách byly jednotlivé fáze výuky realizovány obvykle $v$ určitých dominantních organizačních formách. Souhrnně převažovaly takové organizační formy a fáze výuky, v nichž byl učitel aktivnější než žáci. Ve fázi úvod výuky, rekapitulace, aplikace/prohlubování učiva a zprostředkování nového učiva se ve značné míře uplatňovala forma výkladu/přednášky/instrukce učitele. Ve fázi shrnutí se jako dominantní forma ukázala forma diktátu. Fáze opakování byla realizována ve většině případů formou rozhovoru se třídou. Ve fázi zkoušení/prověrka/kontrola domácího úkolu a procvičování/upevňování učiva převažovala forma samostatné práce.

Pro práci s již probraným učivem se nabízí kromě samostatné práce řada př́ležitostí k uplatnění kooperativních forem práce orientovaných na žáky. Jak ale ukázaly analýzy hodin CPV videostudie zemépisu, velmi malé bylo zastoupení činností podporujících kooperaci žáků - práce ve dvojicích a práce ve skupinách, což můžeme považovat za jeden z nedostatků zkoumané výuky. Důvodů absence kooperativních forem může být celá řada. Za klíčové považujeme značný časový tlak na obsahové 
množství učiva zeměpisu, jehož reálné probrání mnohdy zabraňuje učitelům zařazovat práci ve skupinách, nebot' je časově náročná. Důvodem mohou být věková omezení žáků, kteří do určitého věku nemají dostatečně rozvinuty dovednosti kooperace na požadované úrovni. $V$ prípadě zkoumaných hodin zeměpisu, které probíhaly v 8. a 9. ročníku základní školy nebo v nižším ročníku gymnázia (tercie), by byl rozvoj kooperativních forem výuky již žádoucí.

Poměr verbálních projevů učitele oproti verbálním projevům všech žáků ve třídě dohromady dosahoval hodnoty 5,92. Sledovaní učitelé hovořili v hodině přibližně šestkrát více než všichni žáci dohromady. Mezi jednotlivými vyučovacími hodinami i mezi jednotlivými učiteli však byly shledány relativně velké rozdíly v poměru příležitostí k verbálnímu projevu.

Prezentované analýzy a výsledky se orientují především na jevovou stránku výuky, proto bude nutné usilovat o hlubší analýzy, které umožní proniknout k podstatě sledovaných jevů. Další analýzy se budou zaměřovat spíše na oborově didaktické aspekty výuky zeměpisu - využití map v hodinách zeměpisu, zastoupení učebních úloh podle dimenze kognitivních procesů a další.

\section{Literatura}

AEBLI, H. Zwölf Grundformen des Lehrens. Stuttgart : Klett-Cotta, 2003.

GAVORA, P. Pravidlá komunikácie učitel' - žiaci na základnej škole. Pedagogika, 1987, roč. 37, Č. 2, s. 177-189.

GAVORA, P. Učitel a žáci v komunikaci. Paido : Brno, 2005.

GERBER, R. The Global Scene for Geographical Education. In GERBER, R. (ed). International Handbook on Geographical Education. Dordrecht : Kluwer Academic Publisher, 2003, s. 3-18.

HASPROVÁ, M. Geografie miestnej krajiny v edukačnom procese. In Geografické štúdie. Nitra: UKF, 2006, č. 11, s. 121.

HAUBRICH, H. State of the art in geographical education 1996. In Van der ZIJPP, T.; Van der SCHEE, J.; TRIMP, H. Proceedings. Commision on Geographical Education. Vrije Universiteit Amsterdam, 1996.

HÜBELOVÁ, D. Metodický postup CPV videostudie zeměpisu. In KNECHT, P. (ed.). Výzkum aktuálních problémů pedagogiky a oborových didaktik. Brno : MU, 2006, s. 143-149.

HÜBELOVÁ, D.; JANÍK, T.; NAJVAR, P. Formy a fáze ve výuce zeměpisu: metodologický postup a vybrané výsledky CPV videostudie zeměpisu. In JANÍK, T.; KNECHT, P.; NAJVAROVÁ, V. (ed) Př́spěvky k tvorbě a výzkumu kurikula. Brno : Paido, 2007, S. $153-168$.

JANÍK, T.; MIKOVÁ, M. Videostudie: výzkum výuky založenýna analýze videozáznamu. Brno : Paido, 2006.

MAŇÁK, J. Nárys didaktiky. Brno : PdF MU, 2003.

PSTRUŽINOVÁ, J. Některé pedagogicko-psychologické aspekty učitelových otázek. Pedagogika, 1992, roč. 42, č. 2, s. 223-228. 
RIMMELE, R. Videograph. Multimedia-Player zur Kodierung von Videos. Kiel : IPN, 2002.

SEIDEL, T. Lehr-Lernskripts im Unterricht. Münster : Waxmann, 2003.

SEIDEL, T.; PRENZEL, M.; DUIT, R.; LEHRKE, M. (Hrsg.). Technischer Bericht zur Videostudie "Lehr-Lern-Prozesse im Physikunterricht". Kiel : IPN, 2003.

ŠEĎOVÁ, K. Podoby pedagogické komunikace v české škole. Pedagogika, 2005, roč. 55, č. 4, s. 368-381.

VYSKOČILOVÁ, E.; MATOUŠKOVÁ, A. Výzkum učiva a učení základům zeměpisné orientace $v$ prvouce a vlastivědě. Pedagogika, 1998, roč. 48, č. 1, s. 41-53.

Tato studie vznikla za podpory MŠMT ČR v rámci projektu „Centrum základního výzkumu školního vzděláváni"s registračním číslem LC06046. 